\title{
Buccal apparatus and gastrointestinal tract dimensions associated to the diet of early life stages of Centropomus undecimalis (Centropomidae, Actinopterygii)
}

\author{
Isabela M. S. Araújo ${ }^{1}$, Elisabeth C. Silva-Falcão ${ }^{2} \&$ William Severi ${ }^{1}$
}

1. Departamento de Pesca e Aquicultura, Universidade Federal Rural de Pernambuco, Av. Dom Manoel de Medeiros, s/n, Dois Irmãos, 52171-900 Recife, PE, Brazil. (imsaraujo@ hotmail.com; wseveri@ depaq.ufrpe.br)

2. Departamento de Oceanografia, Universidade Federal de Pernambuco, Av. da Arquitetura, s/n, Cidade Universitária, $50740-550$ Recife, PE, Brazil. (elisabeth_cabral@ hotmail.com)

\begin{abstract}
The present study aims to compare the buccal apparatus and gastrointestinal tract of early life stages of Centropomus undecimalis (Bloch, 1792), and relate them to its diet. A total of 190 individuals collected with a channel net in the Catuama estuary $\left(07^{\circ} 40^{\prime} 9.9^{\prime \prime} \mathrm{S}, 34^{\circ} 50^{\prime} 36.7^{\prime \prime} \mathrm{W}\right)$, northern coast of the state of Pernambuco, were examined. Morphometrical and meristic data were analyzed for the two initial developmental periods (larval and juvenile). Their digestive tube was morphologically characterized and its content identified. The longest transverse axis of food items was measured, and compared to the standard length (SL) and mouth gape size (D) of the individuals. Body measurement regressions differed significantly $(\mathrm{p}<0.001)$ between larvae and juveniles. The stomachs with food content ( $\mathrm{n}=118$ individuals) presented a proportion of $62 \%$ full and $30 \%$ empty (being $8 \%$ damaged). They differed in relation to the fullness level and presented a coiled shape when empty. The number of food items in relation to SL and D did not present an evident correlation. Larvae (SL $<10 \mathrm{~mm}$ ) feed on small copepods, while juveniles ( $\mathrm{SL}=11.1$ to $64.7 \mathrm{~mm}$ ) ingest larvae of various decapod species, showing a distinct diet between these initial developmental stages.
\end{abstract}

KEYWORDS. Gape size, prey size, larvae, juveniles, common snook.

RESUMO. Dimensões do aparato bucal e trato gastrintestinal associado à dieta de estágios iniciais de Centropomus undecimalis (Centropomidae, Actinopterygii). No intuito de comparar o desenvolvimento do aparato bucal e do trato gastrintestinal de fases iniciais de Centropomus undecimalis (Bloch, 1792), relacionando-os com a dieta, foram analisados 190 indivíduos provenientes de coletas realizadas com rede tipo channel net, no estuário de Catuama ( $07^{\circ} 40^{\prime} 9,9^{\prime}$ 'S, 34 $50^{\circ} 36,7^{\prime}$ 'W), litoral norte de Pernambuco. Foram analisados dados morfométricos e merísticos de indivíduos nos dois períodos de desenvolvimento inicial (larval e juvenil). O tubo digestório foi retirado, caracterizado morfologicamente e seu conteúdo identificado. A maior seção transversal dos itens alimentares foi mensurada, para comparação com o comprimento padrão (CP) dos indivíduos e o tamanho de abertura de suas bocas (D). As regressões das medidas corporais diferiram significativamente $(\mathrm{p}<0,001)$ entre as fases larval e juvenil. Os estômagos com alimento ( $\mathrm{n}=118$ indivíduos) apresentaram uma proporção de $62 \%$ cheios e $30 \%$ vazios (sendo $8 \%$ danificados), tendo diferido em relação ao grau de repleção e apresentado forma enovelada quando vazios. O número de itens em relação a $\mathrm{CP}$ e $\mathrm{D}$ não apresentou correlação evidente. As larvas $(\mathrm{CP}<10 \mathrm{~mm})$ alimentam-se de pequenos copépodos, enquanto os jovens $(\mathrm{CP}=11,1$ a $64,7 \mathrm{~mm})$ ingerem larvas de diferentes espécies de decápodos, evidenciando uma dieta diferenciada entre as duas fases iniciais de desenvolvimento.

PALAVRAS-CHAVE. Tamanho da boca, tamanho de presas, larvas, juvenis, camurim.

Food selection by aquatic organisms is based on prey size and abundance, and on the ease with which it can be captured (BRoOKs \& Dodson, 1965). According to MAY (1970) and HUNTER (1981), prey selection by fish depends basically on size, although movement also plays an important role in the predator's ability to seize it. For many fish species, the pattern of prey selection is determined by the position, shape and size of the mouth (AlEXANDER, 1978), which are morphological aspects closely related to feeding habits and food capture form (Zavala-Camin, 1996).

As a result of their complex life history, trophic niches of fish are usually better evidenced during changes in their ontogeny (LuczKovich et al., 1995). According to SCHARF et al. (2000), predator gape opening increases with size, as do the morphological defenses of prey, so that the first attribute to be linked directly to feeding success is the relation between the body sizes of prey and predator.

There is growing interest in the characterization of fish early stage diets in ecological studies (e.g. RocHE \&
RochA, 2005) and in farming conditions (e.g. RIBEIRo \& NUÑER, 2008), due to the importance of feeding during these stages (Planas \& Cunha, 1998) and the high mortality rates during the transition stage between endogenous and exogenous feeding (Houde, 2002). This is particularly important for carnivore species, given the relation between the size of food provided and the dimensions of the buccal apparatus during fish development (KAMLER, 1992).

Centropomidae species inhabit shallow coastal waters, estuaries and brackish lagoons, frequently penetrating freshwater locations (OrRelL, 2002). They feature fusiform body, large head and mandible slightly larger than the maxilla, feeding mainly on fish and crustaceans (FigueiRedo \& Menezes, 1980). They are considered top-quality fish, enjoying widespread market acceptance, with some species reaching up to $130 \mathrm{~cm}$ in total length (ORRELL, 2002).

The snook and common snook comprise 12 species of Centropomus Lacepède, 1802, six of which inhabit the Pacific and the other six the Atlantic (RIvAs, 1986). In 
Brazil, the most important species are Centropomus undecimalis (Bloch, 1792) and C. parallelus Poey, 1860 (FigueIREDO \& MENEZES, 1980), known locally in the southsoutheastern coast as robalo-flecha and robalo-peva, respectively, and as camurim in the northeast region of the country.

Studies on the ecology and diet of early life stages of $C$. undecimalis are scarce. Gilmore et al. (1983) undertook a study on the feeding habits of $C$. undecimalis individuals close to $15 \mathrm{~mm}$ in size; Peters et al. (1998) published an article combining published and unpublished data on the reproduction and early life history of this species in Florida (USA). TEMPLE et al. (2004) analyzed the effect of the reduced density of prey on the growth and behavior of forage in $C$. undecimalis larvae, concluding that an ontogenetic change occurs in common snook feeding during the juvenile stage, from copepods and other microcrustaceans to fish and shrimp.

Some studies have analyzed the ontogenetic changes in the morphology of the digestive tract and the larval diet of some fish species, such as Bryconamericus aff. iheringii (Boulenger, 1887) (BORGEs et al., 2006), Iheringichthys labrosus (Lütken, 1874), Hypophthalmus edentatus Agassiz in Spix \& Agassiz, 1829, Plagioscion squamosissimus (Heckel, 1840) (MAKRAKIs et al., 2005) and Apareiodon affinis (Steindachner, 1879) (SANTIN et $a l ., 2004)$, but this aspect has not been evaluated in $C$. undecimalis so far.

Reflecting their economic importance, data on the biology of the early stage diets of common snook are needed to understand their life cycle, and are essential to manage this important fishery resource, as well as for possible farming initiatives. Moreover, data on early life stages feeding ecology are also essential for understanding trophic relations among larval assemblages in tropical estuarine environments.

In that context, the objectives of the present work are to characterize the dimensions of the buccal apparatus and gastrointestinal tract of common snook $(C$. undecimalis) larvae and juveniles, relating them with early stage diet, and verify the relations between buccal apparatus dimensions and food item size.

\section{MATERIAL AND METHODS}

A total of 190 C. undecimalis individuals were analyzed, originating from collections using a channel net, which is composed by two lateral flaps made with 1$\mathrm{mm}$ mesh nets, each $2 \mathrm{~m}$ long and $2 \mathrm{~m}$ high; a bag consisting of a conic-cylindrical net with $500 \mu \mathrm{m}$ mesh size, $1.70 \mathrm{~m}$ long and $0.6 \mathrm{~m}$ mouth diameter, and collector cup with $300 \mu \mathrm{m}$ mesh size. Samplings were carried out from May 2005 to April 2006, at a tidal creek (0740'9.9' $\mathrm{S}$, $34^{\circ} 50^{\prime} 36.7^{\prime}$ ' $\mathrm{W}$ ) in the Catuama estuary, northern coast of the state of Pernambuco, Brazil. Captured larvae were fixed in $5 \%$ formalin neutralized with $\mathrm{CaCO}_{3}$, and later preserved in $70 \%$ ethanol.

The following morphometric data were analyzed: standard length (SL), head length (HL), pre-dorsal (PDD), pre-pectoral (PPD), pre-pelvic (PPLD) and pre-anus (PAD) distances, body height $(\mathrm{BH})$, eye diameter (ED), upper maxilla length (UML) and mouth gape size (D). All measurements were correlated with SL, including the ratio between ED, UML and D with HL, following the formula $\mathrm{Y}=\mathrm{A}+\mathrm{BX}$. The analysis was carried out for two length classes (greater or less than $10 \mathrm{~mm} \mathrm{SL}$ ) which corresponds to the transition size from larval to juvenile period in $C$. undecimalis, according to RICHARDS (2006). The objective of this morphometric analysis was to investigate differences in the amplitude of size variance of body structures between the two developmental periods, by comparing the respective simple linear regression equations, using the t-test (ZAR, 1996).

The larvae were cleared and stained according to the methodology proposed by Dingerkus \& UHLER (1977), in order to display internal structures such as bones, rays, rakers and vertebrae, as well as to characterize the buccal apparatus. As such, the following meristic data were analyzed: number of rays in the pectoral, pelvic, dorsal, caudal and anal fins; and number of vertebrae and rakers in the lower first gill arch, mainly for taxonomic identification. These analyses were conducted under a stereomicroscope with a micrometer eyepiece, characterizing the developmental periods and larval stages by using the classification of MOSER (1984). All cleared and stained individuals are deposited at the Fish Collection of Laboratório de Ictiologia da Universidade Federal Rural de Pernambuco (LIUFRPE 0115-0123).

After clearing and meristic characterization, the digestive tube was removed for morphological characterization. Their contents were identified to the lower possible taxonomic level using specialized literature (BJöRnBerG, 1963; Boltovskoy, 1981, 1999). The longest transverse axis of each food item was measured ( $\mathrm{mm}$ ) for later comparison with larvae size and its relation to mouth gape size.

In characterizing the digestive tube, stomach and intestine length were considered together and expressed as total tract length (TL), as well as level of coiling, relative position of the anus and placement of gill rakers.

In order to estimate larvae gape size, the methodology proposed by SHIROTA (1970) was applied, through the formula $\mathrm{D}=\sqrt{2 A B}$, where $\mathrm{D}$ is mouth gape size and $\mathrm{AB}$ is the measurement of upper maxilla length (Fig. 1), based on the recommendations found in SHIROTA

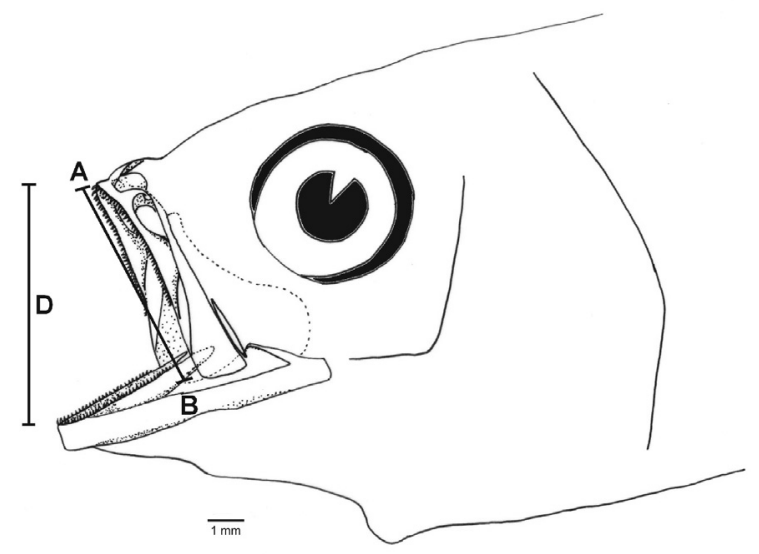

Figure 1. Dimensions of the buccal apparatus of Centropomus undecimalis (Bloch, 1792) (modified from SHIRotA, 1970) (AB upper maxilla length; D, mouth gape size). 
(1978). The correlation between D and prey size was analyzed throughout the ontogenetic development of the larvae, considering that the theoretical size of the maximum width of prey corresponds to $50 \%$ of D (SHIROTA, 1978).

\section{RESULTS}

Morphometric characterization. Of the $190 \mathrm{C}$. undecimalis individuals analyzed, 171 were larvae in postflexion larval stage (SL $=5.6$ to $9.1 \mathrm{~mm}$ ), and 19 in the juvenile developmental period ( $\mathrm{SL}=11.1$ to $64.7 \mathrm{~mm}$ ).

The linear regressions carried out in all individuals between the proportions of HL, PDD, PPD, PPLD, PAD, $\mathrm{UML}, \mathrm{BH}, \mathrm{D}$ and ED in relation to $\mathrm{SL}$, and of ED, UML and $\mathrm{D}$ in relation to HL, showed a positive correlation between them, with statistically significant $(p<0.001)$ Pearson linear correlation coefficients (r). The analysis of these correlations for both developmental periods, in separate, indicated a significant difference $(p<0.001)$ between the simple linear equations obtained for each period, for all body proportions analyzed (Tab. I).

From this analysis, it was possible to observe that individuals larger than the transition size from larva to juvenile (10 $\mathrm{mm} \mathrm{SL}$ ) showed a distinct growth trend. Body proportions were lower in larvae for almost all measurements (Tab. II), except for the UML/SL $(\mathrm{p}<0.001)$ and ED/HL $(\mathrm{p}>0.05)$ ratios, which were lower in juveniles.

Meristic characterization. The number of vertebrae $(10+14, \mathrm{n}=184)$ and rays in pelvic $(\mathrm{I}+5, \mathrm{n}=172)$, caudal $(9+9, \mathrm{n}=182), 1^{\text {st }}$ dorsal $(\mathrm{VIII}, \mathrm{n}=183)$ and $2^{\text {nd }}$ dorsal $(\mathrm{I}+10$, $\mathrm{n}=182$ ) fins did not show any difference among individuals. Alternatively, the pectoral fin showed a difference of two to three rays (13-14 to $16, n=77)$, and the anal fin differed by one spine and one ray (II-III+6-7, $\mathrm{n}=182$ ). With regard to the rakers of the lower first gill arch, seven to eight rakers were observed in the 190 individuals analyzed.

Characterization of the buccal and gastrointestinal apparatus. Centropomus undecimalis individuals have a terminal mouth, caniniform teeth and short rakers, present in all arches (with 7-8 in the first arch), which is typical of carnivore species.

Among all individuals analyzed, larvae and juvenile alike, the only differentiation observed among stomachs was with regard to fullness level. When empty or partially full, the stomach shows coiling (Fig. 2) and the intestine has a tubular form. When full, the stomach dilates and does not show evident coiling, making its differentiation from the intestine more difficult (Fig. 3). Figure 4 shows an empty stomach distended for approximate visualization of its form.

Of the 190 individuals analyzed, $118(62 \%)$ had items in their digestive tract, $57(30 \%)$ were empty and $15(8 \%)$ were damaged. Of the 118 individuals that had items in the digestive tract, nine $(\mathrm{SL}=7.6-18.9 \mathrm{~mm})$ were full and had between 42 and 61 items; ten ( $\mathrm{SL}=7.2-24.4 \mathrm{~mm}$ ) showed 10 to 25 items; and the remaining 99 individuals (SL=5.4-64.7 mm) had less than ten items.

The development of the gastrointestinal tract in relation to standard length also differed according to developmental period $(\mathrm{t}=7.026, \mathrm{p}<0.001)$. In larvae, the tracts showed varying lengths in individuals with
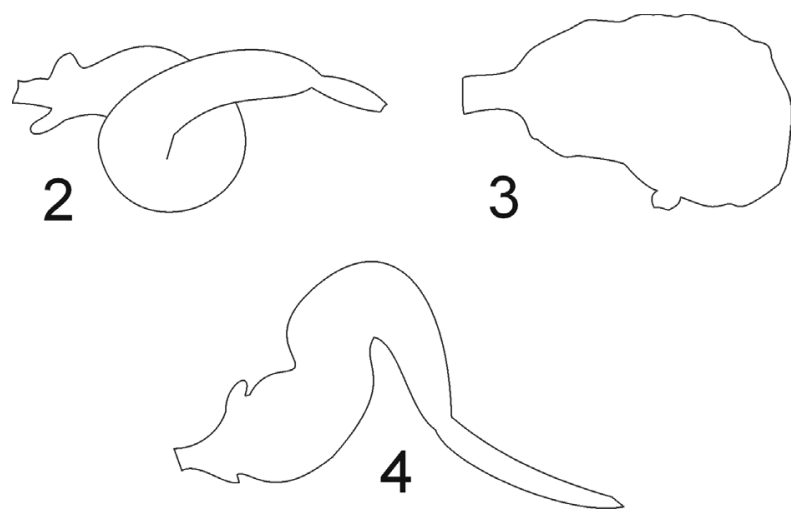

Figures 2-4. Schematic drawing of the stomach of Centropomus undecimalis (Bloch, 1792) individuals: 2, $12.3 \mathrm{~mm}$ SL empty; 3 , $7.9 \mathrm{~mm}$ full; $4,7.1 \mathrm{~mm}$ empty and distended.

Table I. Parameters of the linear regression between the body proportions of Centropomus undecimalis (Bloch, 1792) for the larval and juvenile stages of individuals collected in the Catuama estuary, state of Pernambuco, Brazil, between May 2005 and April 2006 (A, linear coefficient; B, angular coefficient; DF, degree of freedom; n, number of individuals; r, correlation coefficient; t, Student's t-test, * $\mathrm{p}<0.001)$

\begin{tabular}{|c|c|c|c|c|c|c|c|c|c|c|c|}
\hline \multirow{2}{*}{ Ratios } & \multicolumn{5}{|c|}{ Larval stage $(\mathrm{SL}<10 \mathrm{~mm})$} & \multicolumn{5}{|c|}{ Juvenile stage $(\mathrm{SL}>10 \mathrm{~mm})$} & \multirow{2}{*}{$\mathrm{t}^{*}$} \\
\hline & $\mathrm{n}$ & A & $\mathrm{B}$ & $\mathrm{r}^{*}$ & DF & $\mathrm{n}$ & A & $\mathrm{B}$ & $\mathrm{r} *$ & DF & \\
\hline $\mathrm{BH} / \mathrm{SL}$ & 169 & -0.590 & 0.301 & 0.684 & 167 & 18 & 0.579 & 0.251 & 0.990 & 16 & 12.648 \\
\hline $\mathrm{HL} / \mathrm{SL}$ & 170 & -0.403 & 0.387 & 0.895 & 168 & 19 & -0.115 & 0.422 & 0.990 & 17 & 28.538 \\
\hline $\mathrm{PDD} / \mathrm{SL}$ & 169 & -0.261 & 0.433 & 0.809 & 167 & 19 & 0.016 & 0.413 & 0.997 & 17 & 6.749 \\
\hline $\mathrm{PPD} / \mathrm{SL}$ & 167 & -0.097 & 0.355 & 0.819 & 165 & 19 & 0.403 & 0.390 & 0.995 & 17 & 17.620 \\
\hline $\mathrm{PPLD} / \mathrm{SL}$ & 167 & -0.376 & 0.420 & 0.879 & 165 & 19 & -0.669 & 0.462 & 0.997 & 17 & 27.039 \\
\hline $\mathrm{PAD} / \mathrm{SL}$ & 169 & -0.353 & 0.574 & 0.876 & 167 & 19 & 0.430 & 0.566 & 0.996 & 17 & 13.291 \\
\hline $\mathrm{ED} / \mathrm{SL}$ & 156 & 0.039 & 0.083 & 0.666 & 154 & 19 & 0.344 & 0.091 & 0.986 & 17 & 7.516 \\
\hline UML/SL & 167 & -0.493 & 0.216 & 0.762 & 165 & 19 & 0.359 & 0.116 & 0.985 & 17 & 11.038 \\
\hline $\mathrm{D} / \mathrm{SL}$ & 167 & 0.394 & 0.147 & 0.772 & 165 & 19 & 1.459 & 0.040 & 0.978 & 17 & 35.145 \\
\hline ED/HL & 155 & 0.173 & 0.196 & 0.673 & 153 & 19 & 0.379 & 0.214 & 0.986 & 17 & 6.713 \\
\hline UML/HL & 167 & -0.028 & 0.458 & 0.711 & 165 & 19 & 0.419 & 0.274 & 0.980 & 17 & 23.070 \\
\hline $\mathrm{D} / \mathrm{HL}$ & 168 & 0.719 & 0.309 & 0.712 & 166 & 19 & 1.481 & 0.095 & 0.973 & 17 & 40.67 \\
\hline
\end{tabular}


similar SL $(\mathrm{p}<0.005)$. In juveniles, tract growth varied more proportionally to standard length $(\mathrm{p}<0.001)$ (Fig. 5).

The ratio of upper maxilla length (Fig. 6) and mouth gape size (Fig. 7) to standard length, for larval and juvenile periods, showed significant differences between them $(p<0.001)($ Tab. I), with the same variance trend observed previously - more pronounced in smaller individuals.

The variation in food item length was greater in juvenile individuals $(0.22$ to $11 \mathrm{~mm})$ than in larval period individuals (1.1 to $1.8 \mathrm{~mm}$ ) (Fig. 8). This difference in item size between the periods is related to the ample variation of upper maxilla size in relation to standard length between the two periods (Tab. I, Fig. 6). Similarly, the amplitude of item size in relation to mouth gape size (D) (Fig. 9) also

Table II. Mean values of body proportions of larvae and juveniles of Centropomus undecimalis (Bloch, 1792) collected in the Catuama estuary, state of Pernambuco, Brazil, between May 2005 and April $2006\left({ }^{\mathrm{a}}\right.$, in relation to SL; ${ }^{\mathrm{b}}$, in relation to HL; t, Student's t-test; *, p<0.005; **, p<0.001).

\begin{tabular}{|c|c|c|c|}
\hline \multirow[b]{2}{*}{ Measurement } & \multicolumn{2}{|c|}{ Relative mean (\%) } & \multirow[b]{2}{*}{$\mathrm{t}$} \\
\hline & $\begin{array}{l}\text { Larval stage } \\
(\mathrm{SL}<10 \mathrm{~mm})\end{array}$ & $\begin{array}{c}\text { Juvenile stage } \\
(\mathrm{SL}<10 \mathrm{~mm})\end{array}$ & \\
\hline$\overline{\mathrm{BH}^{\mathrm{a}}}$ & 22.38 & 28.07 & $13.157 * *$ \\
\hline $\mathrm{HL}^{\mathrm{a}}$ & 33.06 & 41.51 & $19.649 * *$ \\
\hline $\mathrm{PDD}^{\mathrm{a}}$ & 39.64 & 41.57 & $3.609 * *$ \\
\hline $\mathrm{PPD}^{\mathrm{a}}$ & 34.15 & 40.89 & $15.187 * *$ \\
\hline PPLD $^{a}$ & 36.77 & 42.85 & $14.463 * *$ \\
\hline PAD $^{\mathrm{a}}$ & 52.52 & 58.42 & $10.376 * *$ \\
\hline $\mathrm{ED}^{\mathrm{a}}$ & 8.92 & 10.79 & $10.954 *$ \\
\hline $\mathrm{UML}^{\mathrm{a}}$ & 14.72 & 13.68 & $3.255 * *$ \\
\hline $\mathrm{D}^{\mathrm{a}}$ & 11.67 & 20.28 & $24.540 * *$ \\
\hline $\mathrm{ED}^{\mathrm{b}}$ & 26.98 & 26.17 & 1.516 \\
\hline $\mathrm{UML}^{\mathrm{b}}$ & 33.47 & 44.68 & $9.952 * *$ \\
\hline $\mathrm{D}^{\mathrm{b}}$ & 28.65 & 61.43 & $27.345 * *$ \\
\hline
\end{tabular}

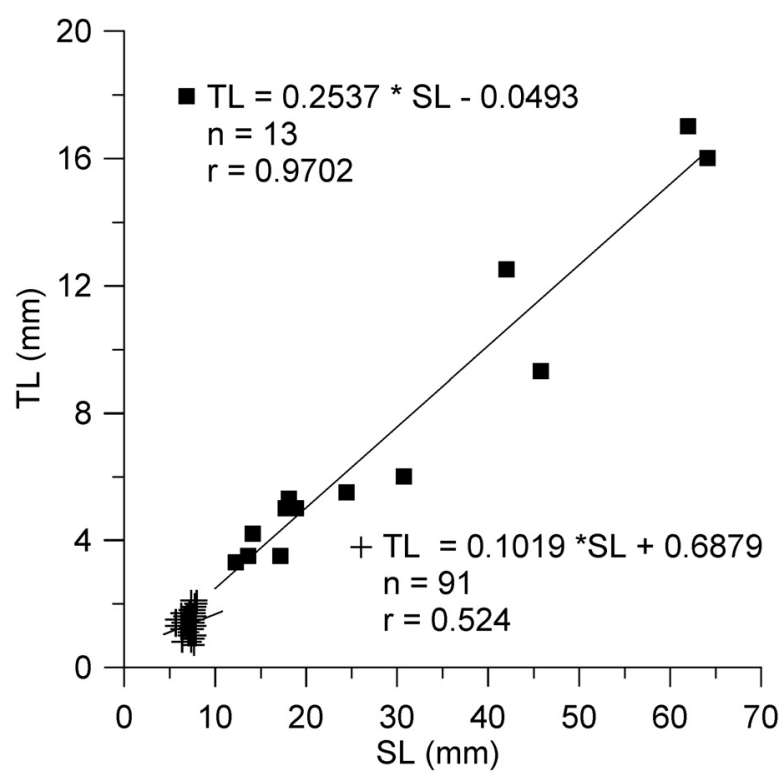

Figure 5. Variation of gastrointestinal tract length (TL) in relation to standard length (SL) for larvae (+) and juveniles ( $\boldsymbol{\square})$ of Centropomus undecimalis (Bloch, 1792) collected in the Catuama estuary, state of Pernambuco, Brazil, between May 2005 and April 2006. differed between the periods, showing a wider variation in individuals with $\mathrm{D}$ greater than $1.5 \mathrm{~mm}$, corresponding to those with SL greater than $10 \mathrm{~mm}$ (Fig. 7).

The number of items in relation to SL and D (Figs $10,11)$ did not show a clear variation trend with individual size. Nevertheless, for both developmental periods, a quantity increase can be observed in the larval period, with a gradual reduction as body size and gape size increase in juveniles.

It can be evidenced that larvae (SL $<10 \mathrm{~mm}$ ) feed on small copepods and cladocerans, whereas juveniles begin to ingest larvae of different decapods, but were not selective for small-sized Calanoida and Cyclopoida copepods, thus characterizing a difference in diet between the two developmental periods (Fig. 12).
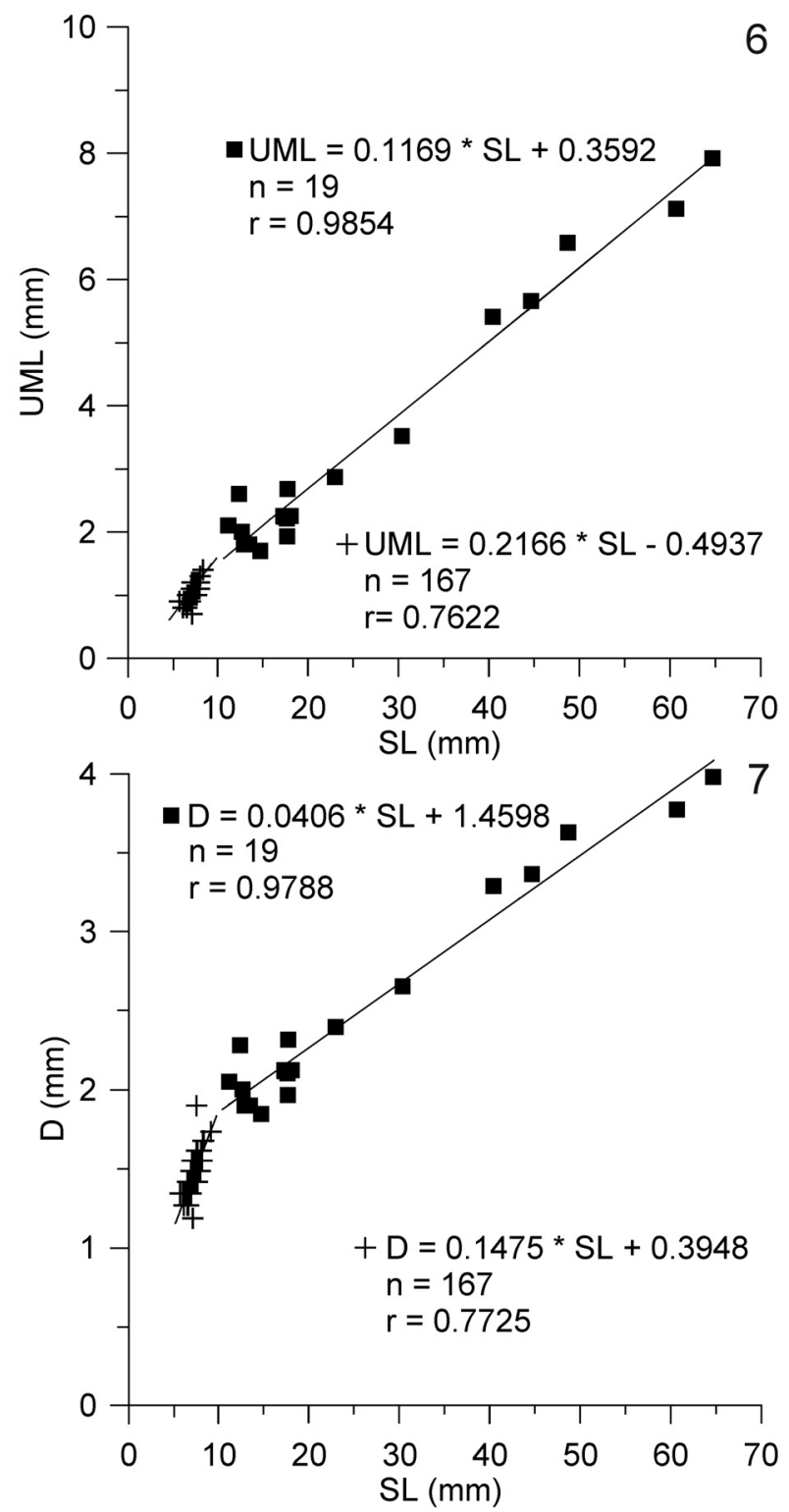

Figures 6, 7. Variation of buccal apparatus measurements in relation to standard length (SL), for larvae (+) and juveniles ( $\square$ of Centropomus undecimalis (Bloch, 1792) collected in the Catuama estuary, state of Pernambuco, Brazil, between May 2005 and April 2006: 6, upper maxilla length (UML); 7, mouth gape size (D). 


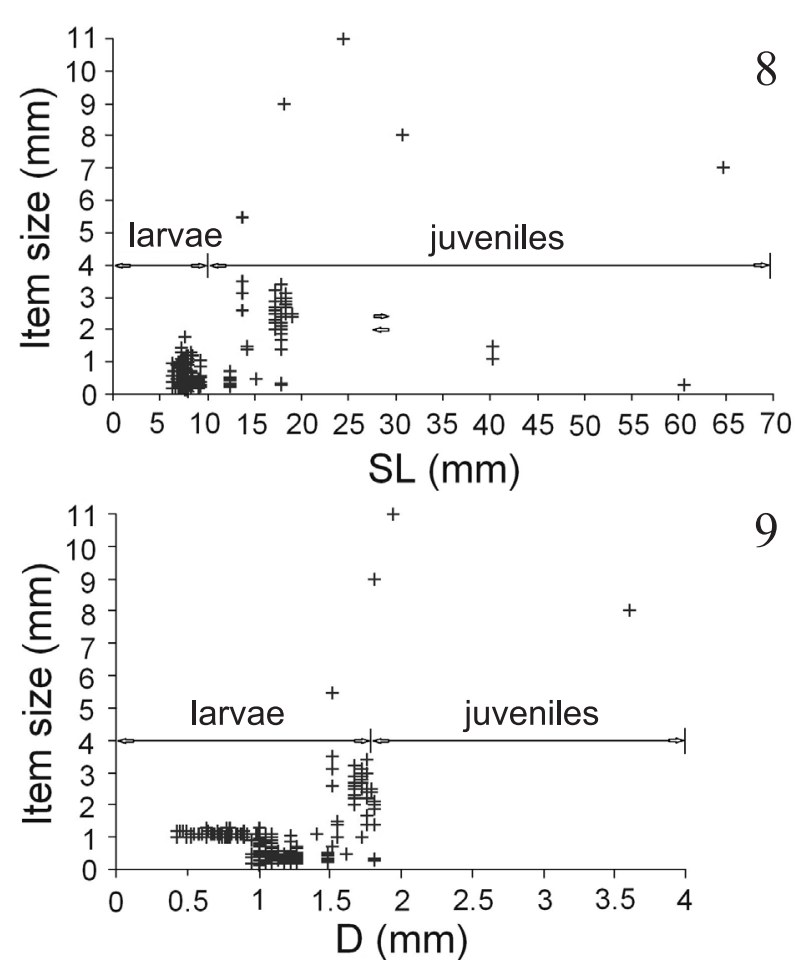

Figures 8, 9. Variation of food item size in relation to body measurements of Centropomus undecimalis (Bloch, 1792) collected in the Catuama estuary, state of Pernambuco, Brazil, between May 2005 and April 2006: 8, standard length (SL); 9, mouth gape size (D).
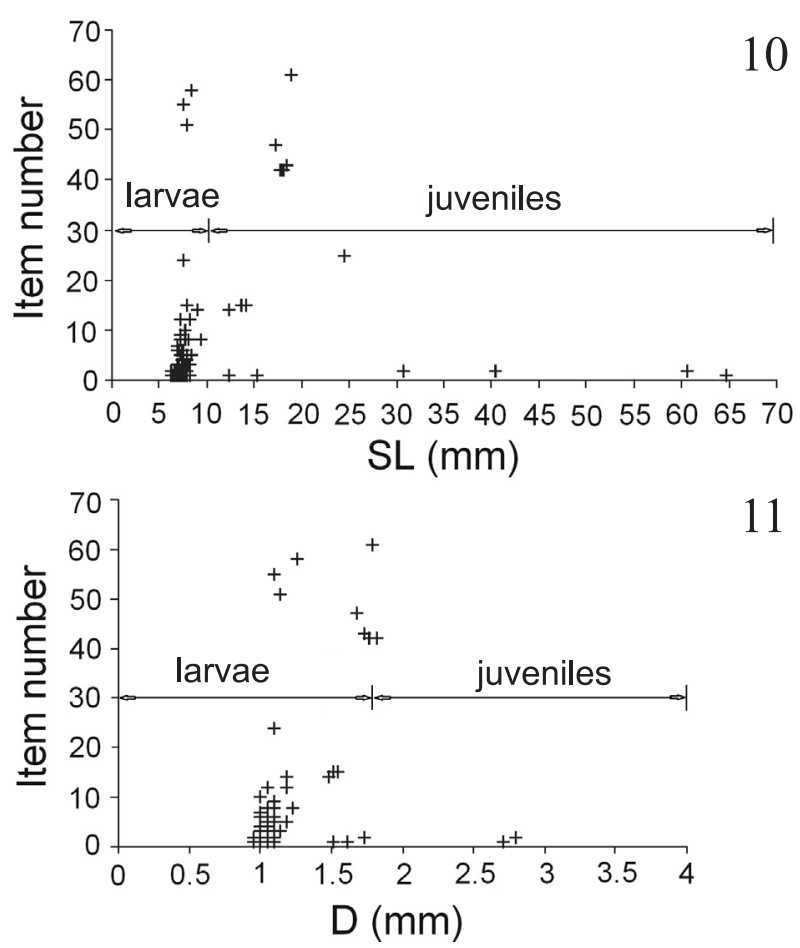

Figures 10, 11. Variation of number of food items in relation to body measurements of Centropomus undecimalis (Bloch, 1792) collected in the Catuama estuary, state of Pernambuco, Brazil, between May 2005 and April 2006: 10, standard length (SL); 11, mouth gape size (D).

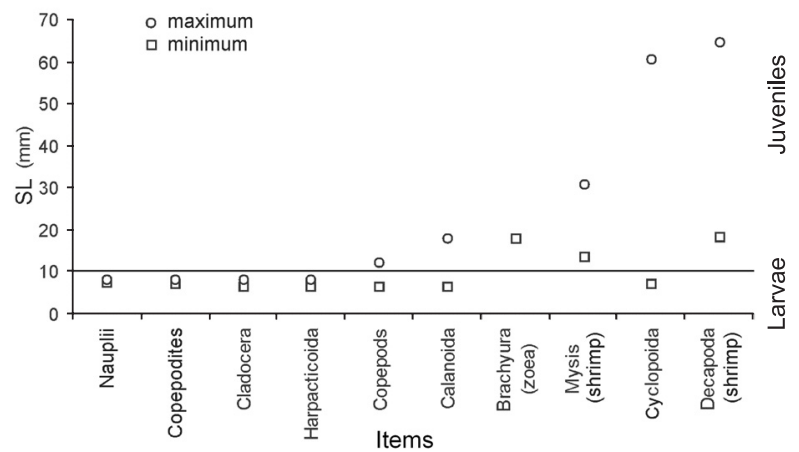

Figure 12. Minimum and maximum sizes (SL) of larvae and juveniles of Centropomus undecimalis (Bloch, 1792) collected in the Catuama estuary, state of Pernambuco, Brazil, between May 2005 and April 2006, in which different food items were recorded.

\section{DISCUSSION}

The number of fin rays and vertebrae of the analyzed individuals did not differ from those cited by Figueiredo \& Menezes (1980), Lau \& Shafland (1982), Rivas (1986), ORRell (2002) and RichaRds (2006) for $C$. undecimalis, independently of habitat or ontogenetic development period considered.

Regression analysis based on body proportions evidenced different trends in the variation of morphometric characteristics, according to developmental period, showing that all measurements presented a higher proportion in juveniles, except for eye diameter and upper maxilla length, which were greater in larvae. This analysis is supported by one of the hypotheses proposed by KovÁc et al. (1999), who demonstrated that changes in morphometric characters can be used to determine the size at which fish undergo transitions. In that sense, it can be demonstrated that $C$. undecimalis does not show an isometric growth pattern, and shows significant difference between the growth rates of larvae and juveniles.

Eye development is faster in larvae than in juveniles, stimulating the development of visual acuity, which is a measurement that determines the distance from which a predator can visualize its prey (FuIMAN, 2002). Differences in visual morphology seem to be more pronounced during the transition from larval to juvenile period (Poling \& Fuiman, 1998), and can determine the success or failure in capturing different-sized prey and evading predators (BlaXTER, 1986). Such feature may be crucial for survival of species inhabiting coastal environments presenting varying visibility characteristics, such as turbid estuary waters and clearer waters near the coast (Fuiman \& Delbos, 1998; Higgs \& Fuiman, 1998a, b).

However, a greater length of upper maxilla in larvae than in juveniles, which is reflected directly on mouth gape size, is not a uniform pattern among fish species, as demonstrated by MAKRAKIS et al. (2005). These authors observed that the differences in mouth gape size were lower in small larvae, increasing with ontogeny in Plagioscion squamosissimus, Iheringichthys labrosus and Hypophthalmus edentatus. Such difference in buccal dimensions between developmental periods seems to be 
related to changes in the way of feeding, coupled with differences in oral anatomy that determine the trophic niche each species occupy throughout their initial development. As for $C$. undecimalis, such differentiation allows the ingestion of larger and more energy-rich preys, such as copepods and shrimp larvae by juveniles.

The morphological and physiological changes that occur during ontogenetic development coincide with habitat changes and promote survival in new environments (BURKE et al., 1995; POLING \& FUIMAN, 1998; Higgs \& Fuiman, 1998a, b). The position, shape and size of the mouth are directly related to diet and to the position in which fish feed in the water column (Helfman et al., 1997; Wооттол, 1998). According to these authors, fish with terminal or dorso-terminal mouths frequently feed at the surface or in the middle of the water column. All $C$. undecimalis individuals analyzed featured terminal mouth, and according to Peters et al. (1998), juvenile common snook have a preliminary pelagic stage followed by a longer demersal phase. The change in feeding habit and habitat, from pelagic to demersal, seems to occur at the transition from larval to juvenile periods in several species (MAKRAKIS et al., 2005). However, other factors apart from mouth position, gape size or prey-capture mechanism limit prey consumption, such as relative availability of prey-resources and ability of larvae to capture large-elusive invertebrate prey (KREBS \& TURIGAN, 2003).

Common snook have short, strong rakers, in reduced number (the smaller one among Centropomus species, according to RIVAS, 1986), which is a characteristic trait of species that feed on large particles (WoOtTon, 1998). Gill rakers are responsible for retaining, by filtering, small food items that could escape through the gill arches along with the water used during breathing (ZAVALACAmin, 1996). Although this author mentions that in carnivore species rakers are usually present only in the first gill arch, in larvae of $C$. undecimalis the presence of rakers and/or rudiments was observed in all gill arches, which suggests that larvae larger than $5.4 \mathrm{~mm} \mathrm{SL}$ already have rakers.

Centropomus undecimalis juveniles (SL $>10 \mathrm{~mm}$ ) with full stomachs showed between one and 61 individual preys, although larger ones (above $30 \mathrm{~mm} \mathrm{SL}$ ) presented only one or two prey items. Similar number of preys was reported by Tonini $e t$ al. (2007), who evaluated the diet of $C$. parallelus juveniles in southern state of Bahia, and observed that around $85 \%$ of individuals had only one item in their stomachs, with no individual showing more than three items. The authors suggest that, after eating, this species possibly waits until its stomach is completely empty before eating again. A possible explanation for the difference between the species may be prey availability and their adaptations in eating activity, in order to avoid competition and trophic niche overlap, since both species usually coexist in estuaries along the northeastern Brazilian coast. Vertical circadian flows of zooplankton, resulting in different prey density at different depths and times of the day, may favor or hinder their access to larvae, in response to predation risk, as has been demonstrated by MELo JúnIOR et al. (2007), in estuaries in the same region of the present study.
The lack of a direct correlation between gastrointestinal tract length and standard length in $C$. undecimalis larvae may be related to the wide variation in the quantity of items found in the stomach and its resulting dilation. This change in shape hindered the differentiation between stomach and intestine as well as the evaluation of the proportion between stomach and intestine size in relation to the organisms' size.

The body proportions between upper maxilla length and mouth size showed a significant difference between larvae and juveniles, which corresponds to the difference between the size of items ingested, coinciding with a threshold SL of $10 \mathrm{~mm}$ and a corresponding D value around $1.5 \mathrm{~mm}$.

The size of food items in relation to SL and D varied according to ontogenetic development in $C$. undecimalis. For the larval period, there was little variation in food item size amplitude, meaning that larvae showed preference for a given prey size, with little amplitude variation. Juveniles, in contrast, showed greater amplitude in food item size, indicating that the size of ingested prey increases in larger predators, whereas the minimum size of ingested prey changes little for a wide range of predator sizes (SCHARF et al., 2000). The intake of small prey by different size classes and an increasing variation in prey size with growth has been recorded for other carnivore species (Holt \& Holt, 2000). According to Magnhagen $\&$ Hеiво (2001), predator mouth gape size and prey body height are the main factors that determine whether a piscivore with limited gape size can ingest its prey.

For most species, due to the difference in size between larvae and adults, the main diet ontogenetic change is in food size, which may or may not be accompanied by a change in its nature as well (ZAVALACAmin, 1996). In C. undecimalis, in addition to the difference observed in the size of items ingested by larvae and juveniles, a difference in diet composition has also been recorded, with larvae feeding on small copepods, while juveniles fed on various decapods.

According to SANTIN et al. (2004), the diet of fish larvae is essentially different from that of adults, as the former are poorly developed and possess a little differentiated digestive system. Peters et al. (1998) recorded that ontogenetic changes in the diet of $C$. undecimalis occur during the juvenile stage, and that they initially ingest copepods and other microcrustaceans, which are later replaced by fish and shrimp. MicMichaeL et al. (1989) showed evidence of ontogenetic changes in the diet of $C$. undecimalis around $45 \mathrm{~mm} \mathrm{SL}$. In smaller sizes, the individuals fed on copepods and mysids; while juveniles fed on cyprinodontids and poeciliids. GILMORE et al. (1983) evaluated the diet of 99 specimens of common snook collected from freshwater tributaries (13-195 mm $\mathrm{SL}$ ) and revealed that smaller individuals prey mainly on microcrustaceans, whereas the larger ones (greater than $100 \mathrm{~mm} \mathrm{SL}$ ) prey mainly on fish and shrimp. This author goes on to cite that a juvenile common snook $(>11 \mathrm{~mm}$ SL) also ingested fish, an item not found in the individuals analyzed herein, even in those common snook with up to $65 \mathrm{~mm}$ SL. The absence of fish in gut contents of $C$. undecimalis juveniles analyzed may be related to their size range ( $\mathrm{SL}=11$ to $65 \mathrm{~mm})$ and crustacean prey 
availability in the Catuama estuary (Melo JÚNIOR et al., 2007). These various works indicate a pattern of change in the diets of larvae and juvenile similar to the present study; from small microcrustaceans to fish and shrimp. According to WoOtTon (1998), these changes in fish diet during growth probably reflect morphological and maturation changes, particularly the increase in mouth size and swimming ability.

Modifications in the use of feeding resources by predator fishes may result from interactions between external and internal conditions, such as anatomical structures, behavioral changes and taxonomic diversity of prey, which occur during ontogeny (Luczкоvich et al., 1995). These authors observed that the maximum size of ingested prey was smaller than the maximum mouth gape size, which suggests that mouth size limits the size of items captured by $C$. undecimalis juveniles. As such, individuals with larger mouth size are able to ingest larger prey and are therefore not selective for smaller-sized prey (HоLт \& Holt, 2000). This fact explains the presence of small prey also in the diet of larger juveniles, as observed herein.

Acknowledgments. The authors thank Xiomara F. G. Diaz for helping in zooplankton identification. To Programa de PósGraduação em Recursos Pesqueiros e Aquicultura (PPG-RPAq/ UFRPE) and Coordenação de Aperfeiçoamento de Pessoal de Nível Superior (CAPES), for the scholarship provided to IMSA. To Projeto RECOS: Uso e Apropriação de Recursos Costeiros (CNPq/ MCT), for the use of facilities in field activities.

\section{REFERENCES}

Alexander, R. M. 1978. Functional design in fishes. 3.ed., London, Hutchinson \& Co. 160p.

BJöRnBERG, T. K. S. 1963. On the free-living copepods off Brazil. Boletim do Instituto Oceanográfico da Universidade de São Paulo 13(1):1-142.

BlaXTER, J. H. S. 1986. Development of sense organs and behavior of teleost larvae with special reference to feeding and predator avoidance. Transactions of the American Fisheries Society 115:98-114.

Boltovskoy, D. 1981. Atlas del zooplancton del Atlántico Sudoccidental y métodos de trabajo con el zooplancton marino. Mar del Plata, INIDEP. 936p.

1999. South Atlantic zooplankton. Leiden, Backhuys. 1706p.

Borges, R. Z.; Assakawa, L. F.; Cunha. A. B.; Bialetzki, A. \& NaKatani, K. 2006. Morfologia do trato digestório e dieta de larvas de Bryconamericus aff. iheringii (Boulenger, 1887) (Osteichthyes, Characidae). Acta Scientiarum. Biological Sciences 28(1):51-57.

Brooks, J. L. \& Dodson, S. I. 1965. Predation body size, and composition of plankton. Science 150:28-65.

Burke, J. S.; TanaKa, M. \& Seikai, T. 1995. Influence of light and salinity on behaviour of larval Japanese flounder (Paralichthys olivaceus) and implications for inshore migration. Netherlands Journal of Sea Research 34(1-3):59-69.

Dingerkus, G. \& UhleR, D. 1977. Enzyme clearing of alcian blue stained small vertebrates for demonstration of cartilage. Stain Technology 52(4):229-232.

Figueiredo, J. L. \& Menezes, N. A. 1980. Manual de peixes marinhos do sudeste do Brasil. II Teleostei (2). São Paulo, Museu de Zoologia, Universidade de São Paulo. 90p.

Fuiman, L. A. 2002. Special considerations of fish eggs and larvae. In: Fuiman, L. A. \& Werner, R. G. eds. Fishery science: the unique contributions of early life stages. Oxford, Blackwell Science. p.1-32.

Fuiman, L. A. \& Delbos, B. C. 1998. Developmental changes in visual sensitivity of red drum, Sciaenops ocellatus. Copeia 1998(4):936-953.
Gilmore, R. G.; Donohoe, J. C. \& Cooke, D. W. 1983. Observation on the distribution and biology of east central Florida population of the common snook, Centropomus undecimalis (Pisces: Centropomidae) en Tunas de Zazá, Cuba. Revista de Investigaciones Marinas, Universidad de la Habana 3(1): 159-200.

Helfman, G. S.; Collette, B. B. \& Facey, D. E. 1997. The diversity of fishes. Malden, Blackwell Science. 528p.

Higgs, D. M. \& Fuiman, L. A. 1998a. Associations between behavioural ontogeny and habitat change in clupeoid larvae. Journal of the Marine Biological Association of the United Kingdom 78:1281-1294.

1998b. Associations between sensory development and ecology in three species of clupeoid fish. Copeia 1998(1):133-144.

Holt, G. J. \& Holt, S. A. 2000. Vertical distribution and the role of physical processes in the feeding dynamics of two larval sciaenids Sciaenops ocellatus and Cynoscion nebulosus. Marine Ecology Progress Series 193:181-190.

Houde, E. D. 2002. Mortality. In: Fuiman, L. E. \& Werner, R. G. eds. Fishery science: the unique contributions of early life stages. Oxford, Blackwell Science. p.64-87.

Hunter, J. R. 1981. Feeding ecology and predation of marine fish larvae. In: LASKER, R. ed. Marine fish larvae: morphology, ecology, and relation to fisheries. Washington, Sea Grant Program. p.33-79.

KAMLER, E. 1992. Early life history of fish: an energetics approach. London, Chapman \& Hall. 267p.

Kovác, V.; Copp, G. H. \& Francis, M. P. 1999. Morphometry of the stone loach, Barbatula barbatula: do mensural characters reflect the species' life history threshold? Environmental Biology of Fishes 56:105-115.

Krebs, J. M. \& Turigan, R. G. 2003. Intraspecific variation in gape-prey size relationships and feeding success during early ontogeny in red drum, Sciaenops ocellatus. Environmental Biology of Fishes 66:75-84.

Lau, S. R. \& Shafland, P. L. 1982. Larval development of snook, Centropomus undecimalis (Pisces: Centropomidae). Copeia 1982(3):618-627.

Luczkovich, J. J.; Stephen, F. N. \& Gilmore JR., R. G. 1995. The influence of oral anatomy on prey selection during the ontogeny of two percoid fishes, Lagodon rhomboides and Centropomus undecimalis. Environmental Biology of Fishes 44:79-95.

Magnhagen, C. \& Heibo, E. 2001. Gape size allometry in pike reflects variation between lakes in prey availability and relative body depth. Functional Ecology 15(6):754-762.

Makrakis, M. C.; Nakatani, K.; Bialetzki, A.; Sanches, P. V.; Baumgartner, G. \& Gomes, L. C. 2005. Ontogenetic shifts in digestive tract morphology and diet of fish larvae of the Itaipu Reservoir, Brazil. Environmental Biology of Fishes 72:99-107

MAY, R. C. 1970. Feeding larval marine fishes in the laboratory: a review. California Cooperative Oceanic Fisheries Investigation Reports 14:76-86.

Melo Júnior, M.; Paranaguá, M. N.; Schwamborn, R.; Leitão, S. N. \& EkAU, W. 2007. Fluxes of zooplankton biomass between a tidal estuary and the sea in Northeastern Brazil. Brazilian Journal of Oceanography 55(4):239-249.

MicMichael Jr., R. H.; Peters, K. M. \& Parsons, G. R. 1989. Early life history of the snook, Centropomus undecimalis, in Tampa Bay, Florida. Northeast Gulf Science 10(2):113-125.

Moser, H. G. 1984. Morphological and functional aspects of marine fish larvae. In: LASKER, R. ed. Marine fish larvae: morphology, ecology, and relation to fisheries. Washington, Sea Grant Program. 131p.

Orrell, T. M. 2002. Order Perciformes. Suborder Percoidei. Centropomidae. Snooks. In: CARpenter, K. E. ed. The living marine resources of the Western Central Atlantic. FAO Species Identification Guide for Fishery Purposes and American Society of Ichthyologists and Herpetologists Special Publication No.5. v.2. Rome, FAO. p.1286-1293.

Peters, K. M.; Matheson JR., R. E. \& Taylor, R. G. 1998. Reproduction and early life history of common snook, Centropomus undecimalis (Bloch), in Florida. Bulletin of Marine Science 62(2):509-529. 
Planas, M. \& Cunha, I. 1998. Larviculture of marine fish: problems and perspectives. Aquaculture 177(1-4):171-190.

Poling, K. R. \& Fuiman, L. A. 1998. Sensory development and its relation to habitat change in three species of sciaenids. Brain, Behavior and Evolution 52:270-284.

Ribeiro, D. F. O. \& NuñER, A. P. O. 2008. Feed preferences of Salminus brasiliensis (Pisces, Characidae) larvae in fish ponds. Aquaculture 274(1):65-71.

Richards, W. J. 2006. Early stages of Atlantic fishes: an identification guide for the western central North Atlantic. Boca Raton, CRC Taylor \& Francis. v.1, 1335p.

Rivas, L. R. 1986. Systematic review of the perciform fishes of genus Centropomus. Copeia 1986(3):579-611.

Roche, K. F. \& Rocha, O. 2005. Aspectos de predação por peixes em lagos e represas, com enfoque na planctivoria. In: RocHE, K. F. \& Rосна, O. orgs. Ecologia trófica de peixes: com ênfase na planctivoria em ambientes lênticos de água doce no Brasil. São Carlos, RIMA. p.1-24.

Santin, M.; Bialetzki, A. \& Nakatani, K. 2004. Mudanças ontogênicas no trato digestório e dieta de Apareiodon affinis (Steindachner, 1879) (Osteichthyes, Parodontidae). Acta Scientiarum. Biological Sciences 26(3):291-298.

Scharf, F. S.; Juanes, F. \& Rountree, R. A. 2000. Predator sizeprey size relationships of marine fish predators: interspecific variation and effects of ontogeny and body size on trophicniche breadth. Marine Ecology Progressive Series 208:229-248.

Shirota, A. 1970. Studies on the gape size of fish larvae. Bulletin of the Japanese Society of Fisheries Oceanography 36:35-368

1978. Studies on the gape size of fish larvae. II: Specific characteristics of the upper jaw length. Bulletin of the Japanese Society of Fisheries Oceanography 44:1171-1177.

Temple, S.; Cerqueira, V. R. \& Brown, J. A. 2004. The effects of lowering prey density on the growth, survival and foraging behaviour of larval fat snook (Centropomus parallelus Poey, 1860). Aquaculture 233(1-4):205-217.

Tonini, W. C. T.; Braga, L. G. T. \& Vila Nova, D. L. D. 2007. Dieta de juvenis de robalo Centropomus parallelus Poey, 1860 no sul da Bahia, Brasil. Boletim do Instituto de Pesca 33(1):85-91.

Wootton, R. J. 1998. Ecology of teleost fishes. 2. ed. Dordrecht, Kluwer Academic. 386p.

ZAR, J. H. 1996. Biostatistical analysis. Upper Saddle River, Prentice-Hall. 662p.

Zavala-Camin, L. A. 1996. Introdução aos estudos sobre alimentação natural em peixes. Maringá, Nupélia/Eduem. $129 \mathrm{p}$.

Recebido em agosto de 2010. Aceito em março de 2011. ISSN 0073-4721

Artigo disponível em: www.scielo.br/isz 